International Journal of Social Science (IJSS)

Vol.1 Issue.5 February 2022, pp: 739-746

ISSN: 2798-3463 (Printed) | 2798-4079 (Online)

\title{
THE ANALYSIS OF VILLAGE FUND CONTRIBUTION TO ACHIEVE A NATIONAL SUSTAINABLE DEVELOPMENT GOAL (SDGs VILLAGE) IN GADINGREJO VILLAGE, KEPIL SUBDISTRICT WONOSOBO REGENCY
}

\author{
By \\ Ahmad Subekti \\ Sekolah Tinggi Pembangunan Masyarakat Desa "APMD" Yogyakarta \\ Email: bektiahmad807@gmail.com
}

\begin{abstract}
Article Info
Articlehistory:

Received Nov 19, 2021

Revised Dec 21, 2021

Accepted Jan 29, 2022

\section{Keywords:}

Village Fund; Sustainable

Development; Sustainable

Development Goals on Village

ABSTRACT

One of the goals of the Village Fund disbursement is to be able to contribute to accelerating the achievement of sustainable national development goals (SDGs Desa). However, in reality, the allocation of the Village Fund which has entered its eighth year carried out by the village government often does not consider sustainable development factors. stated that for villages in Indonesia, the localization of SDGs into Village SDGs was really needed. In fact, the Village SDGs are the main reference for the medium-term development of villages throughout Indonesia. The proven SDGs make it easier to measure development. The measure itself is comprehensive on aspects of people's lives and their environment. Therefore, the localization of SDGs as Village SDGs makes the direction of village development clear and detailed in holistic goals, namely the real contribution of using Village Funds to accelerate the achievement of sustainable national development goals. By using qualitative methods (Cresswel, 2015), this study examines how the problem of the contribution of the Village Fund in sustainable development in Gadingrejo Village, Kepil District, Wonosobo Regency. This study will use the approach proposed by A. Halim Iskandar (2020) regarding the Village SDGs to Accelerate the Achievement of Sustainable National Development Goals. The research findings describe six dimensions, namely (1) Prosperous Villagers (2) Natural balance (3) Village prosperity (4) Peace (5) Partnership and (6) Village Institutions and Wisdom. The contribution of village funds in Gadingrejo Village to finance and maximize the six dimensions mentioned above has not been fully achieved.
\end{abstract}

Thisisan open accessarticleundertheCC BY-SAlicense.

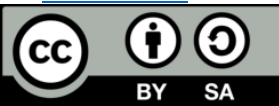

\section{CorrespondingAuthor:}

Ahmad Subekti

Sekolah Tinggi Pembangunan Masyarakat Desa "APMD" Yogyakarta

Email: bektiahmad807@gmail.com

\section{INTRODUCTION}

The purpose of Sustainable Development is to maintain people's prosperity improvement continuously, maintain the sustainability of the social life in the community, preserve the quality of life and inclusive development, and the implementation of governance that can maintain the improvement of the quality of people's lives from one generation to the next.The SDGs with a global scope was ratified in Indonesia as the Sustainable Development Goals in the national context. As in today's position, the SDGs have been integrated into the national development agenda, subsequently to all regions, especially at the Provincial levels. Some Municipals/Regency levels have followed up the agenda by integrating SDGs into their regional development agenda.

The fundamental issue being the center of the question is how to ratify it to the village's level? Although, post-enactment and implementation of Village Act Number 6 of 2014, which now has passed eight years old, has changed the village development paradigm. The village, which was back then as an object of development, is now simultaneously becoming the subject and object. Village development planning is the process of activities stages held by village officials involving BPD and some elements from the community, participative, to utilize and allocate 
village resources to achieve the village development objectives. Village development planning should focus on the village's characteristics and reality which was undoubtedly different from regional autonomy in which the latter is the manifestation of decentralization principles. Meanwhile, village self-reliance departs from the recognition principle (acknowledgment and tribute) and solidarity (localization of village-based authority and decision-making or can be referred to as the application of village-scale local authority).

In preparing the Village Development Plan, the Village Government must depart from the village authority by referring to the Regency/City development planning. Village planning is not just making proposals submitted to the regional government; more importantly, village planning is a political decision taken jointly by the village government and village communities.Regarding village authority which is the basis for village planning, this stipulation is emphasized in Article 34 of Government Regulation Number 43 of 2014 concerning implementing Villages Act Number 6 of 2014.

The utilization of such village funds is an essential and fundamental aspect which stakeholders at the village government level must have this knowledge to establish equitable development, especially at the village level, such as village heads and village officials in establishing village financial transparency and accountability. The basic principles for managing village funds start from the planning stage to reporting, village financial accountability and the duties, and village officials'responsibilities. Based on the Ministry of Home Affairs Regulation No. 20 of 2018 concerning village financial management, the management of village funds must be carried out in a transparent, accountable, participatory, orderly, and budgetary discipline. The period of village fund management starts from January 1 to December 31 of the current year, which must be stated in the Village Budget.

This study will examine the Village Funds' contribution in accelerating village development to achieve national sustainable development goals in Gadingrejo Village, Kepil Subdistrict, Wonosobo Regency. The conceptual framework used in reviewing the focus of this research is the concept put forward by A. Halim Iskandar (2020) regarding the principle of achieving accelerated sustainable national development down to the village level. According to him, it is a derivative of the SDGs and sustainable development goals built on five dimensions. The Village SDGs are also built on the exact dimensions, with the addition of one dimension to six dimensions, e.g., (1) Prosperous People (2) Natural balance (3) Village prosperity (4) Peace (5) Partnership and (6) Village Institutions and Wisdom. In collecting data, the method used is conducting observations, interviews with informants, and documentation. Then, the data obtained is processed and analyzed in stages, starting with data reduction, displaying the data, and drawing research conclusions.

In reality, on the ground, unsustainable development can be seen in the development process in Gadingrejo village, where the COVID-19 pandemic has resulted in the sustainable development goals contained in the village development planning document, which have been agreed with the community.

\section{RESEARCH METHOD}

This research applied a qualitative method using a descriptive approach. Denzin \& Lincoln in Creswell (2015) state that qualitative research is an activity located in a specific site and puts the researcher in the world. Qualitative research consists of material interpretive practices that make the world visible. These practices are transforming the world. They turn the world into a series of representations, including field notes, interviews, conversations, photographs, recordings, and personal notes. In this case, qualitative research involves a naturalistic interpretive approach to the world. This approach means that qualitative researchers study objects in their natural environment, trying to make sense of or interpret phenomena from the point of view of the meanings given to them by society. This method searches for thorough thinking through direct observation in Gadingrejo Village.

In collecting the data, the writer interviewed actors and parties involved in the implementation of village fund management in Gadingrejo Village: they are the village head, village officials, community public figures, and residents in the community. The authors then apply the data and facts in the field to carry out the theoretical analysis. Meanwhile, different sources and data obtained were triangulated and applied as the basis of analysis for data validation.

\section{RESULTS AND DISCUSSION}

\section{Sustainable Development}

The global development agenda in 2030 (A. Halim Iskandar, 2020), known as the SDGs, is not finished only with a global declaration by UN member countries. Although juridically, the SDGs are not a legally binding global plan, as a joint commitment, it is inevitable that the SDGs are not confident that the SDGs must be ratified by a country that is a signatory to the SDGs into its development planning document.As a global initiative that emphasizes the spirit of inclusiveness and participation, within the framework of the preparation and implementation of the SDGs at the national and regional levels, it indeed cannot be separated from a holistic approach and strategy 
International Journal of Social Science (IJSS)

Vol.1 Issue.5 February 2022, pp: 739-746

ISSN: 2798-3463 (Printed) | 2798-4079 (Online)

DOI: https://doi.org/10.53625/ijss.v1i5.1318

between economic development, social inclusion, and environmental sustainability, while still prioritizing the nation's priority and characteristics.

For pursuing Indonesia's commitment to implementing the SDGs, the gesture was shown when the Vice President of the Republic of Indonesia, H.M. Jusuf Kalla,presentedat the United Nations General Assembly for the signing of the SDGs in 2015 which contained SDGs mainstreams of 17 goals and 169 targets by 2030 in the national development agenda, with an inclusive and participatory approach, prioritizing local wisdom and on top of that no one left behind.In order to ratify it at the national level, in the same year, the cabinet meeting of "Indonesia Kerja"formulates several decisions, including preparing a draft documentof the legal framework for the SDGs implementation starting with the principles of openness and participatory, with the involvement of the community, universities, and the Civil Society Coalition for the SDGs.More specifically and concrete steps, in the following year, President Joko Widodo signed Presidential Regulation (Perpres) Number 59 of 2017 concerning the Implementation of Achieving Sustainable Development Goals. This regulation contains 17 Sustainable Development goals regulates the role of each ministry, institution, and the role and involvement of non-government stakeholders, such as civil society groups, academics, philanthropists, and business actors, in achieving the Sustainable Development Goals (TPB).

The Presidential Regulation above contains at least three essential mandates for the central and regional governments to follow up and implement. The first is the preparation of the National Roadmap for Sustainable Development Goals as a plan document that contains strategic policies for the stages to achieve the National Development Goals from 2016 to 2030 conforming with national development targets. The second is the preparation of the National Action Plan for Sustainable Development Goals, a document containinga five-year program and work plan activities to implement various activities, which directly and indirectly support SDGs achievement conforming to the national development targets. The third is the preparation of the Regional Action Plan for Sustainable Development Goals, as a five-year work plan document for the implementation of various activities, which directly and indirectly support the achievement of the Sustainable Development Goals following regional development targets.

The Sustainable Development Goals contained in Presidential Regulation Number 59 of 2017, as a derivative manifestation of the SDGs, are as follows:

a. Without poverty, there is no poverty of any kind throughout Indonesia.

b. No Hunger, there is no hunger by achieving food security and sustainable agriculture.

c. Healthy and Prosperous Life, encouraging and realizing a healthy and prosperous life for all ages.

d. Qualifiededucation ensures equal distribution of qualified education and increases learning opportunities for everyone.

e. Gender Equality by establishing gender equality and empowering women.

f. Clean Water and Adequate Sanitation, ensuring the availability of clean water and sustainable sanitation for everyone.

g. Clean and Affordable Energy, by ensuring access to affordable, reliable, sustainable, and modern energy sources for everyone.

h. Decent Work and Economic Growth to support and facilitate sustainable economic development, productive employment, and decent work for all.

i. Industry, Innovation, and Infrastructure builds qualified infrastructure and encourages innovation and sustainable industry improvement.

j. Reducing inequality, reducing inequality both between citizens and between regions in Indonesia.

k. Sustainable Cities and Communities, building qualified, safe and sustainable cities and settlements.

1. Responsible Consumption and Production, ensuring sustainable consumption and environmentally friendly production.

m. Addressing Climate Change, respond quickly to address climate change and its impacts.

n. Marine Ecosystems conserve and maintain the sustainability of the Indonesian oceans and the life of marine resources.

o. Terrestrial Ecosystems protect, restore, and enhance the sustainable use of terrestrial ecosystems and manage them sustainably.

p. Peace, Justice, and Strong Institutions promote community peace for sustainable development and provide access to justice for all.

q. Partnerships to Achieve Goals revitalize and revive global partnerships, and regional partnerships for sustainable development. 
Sumodiningrat (2016) said that to build means a process of structural changes toward happiness (prosperous). Humans are born-live-die-regenerate. Building process includes constructing a familyarea. Building a nation starts from personal-family-village (smallest government decision-making unit). Thus, it can be said that development is a process of changing the structure of society based on its capabilities. This process requires five development activities that are inseparable and form a circular flow, i.e., (1) production and job creation to (2) increase income to (3) increase beneficial savings for (4) capital formation to create (5) technological change. Technological changes, in turn, will have a positive impact on increasing production and employment.

Oekan S Abdullah (2017) said that several principles are needed in sustainable development:

a. The development approach in the economic aspect of sustainable development focuses on increasing workers' skills to increase competitiveness in obtaining decent work. In addition, sustainable development encourages strategic economic cooperation and increases the performance of basic infrastructures such as housing, water, roads, and access to information. Energy Saving energy is part of sustainable development. One application optimizes the building structure with as much natural light as possible.

b. Ecology in sustainable development is applied through mixed land to the maximum, paying attention to green open spaces, transportation systems, and interconnected development and limiting excessive urban expansion.

c. Equity, The main goal of sustainable development is equity. Equity is deemed to suppress economic and social disparities and provide equal opportunities in society.

Sustainable development engagement is carried out by increasing and maximizing the participation of the community. There are several principles of sustainable development in community participation, e.g., Intergenerational justice in which each generation has the right to receive and occupy the Earth in good conditions, not bad conditions due to previous generations. Justice in a generation where the burden of environmental problems must be shared. The principle of early prevention When a threat occurs that causes irreversible environmental damage. Prevention of environmental damage must be done immediately in order to protect biodiversity. So the contribution of sustainable development is to provide material and non-material by the government so that it can be used in more optimal development and conforming to achieve the goals for the benefit and welfare of the community.

Furthermore, A. Halim Iskandar (2020) stated that for villages in Indonesia, localization of SDGs into Village SDGs is very much needed. The Village SDGs are the primary reference for the medium-term development of villages throughout Indonesia. SDGs are proven to make it easier to measure development. The measure itself is comprehensive on aspects of people's lives and environment. Therefore, localizing the SDGs as Village SDGs makes the direction of village development clear and detailed in holistic goals.

The SDGs location is formulated as Village SDGs as shown in the following table:

a. SDGs Village number 1: Village Without Poverty, this diction was chosen instead of no poverty or ending poverty.

b. SDGs Village number 2: Village Without Hunger, this diction was chosen over zero hunger or ending hunger.

c. SDGs Village number 3: Healthy and Prosperous Village, this diction was chosen instead of good health and wellbeing.

d. SDGs Village number 4: Quality Village Education, this diction was chosen over quality education.

e. SDGs Village number 5: Village WomenInvolvement, this diction is rather than gender equality because it shows the more dominant problem in the village to achieve gender equality is to increase womeninvolvement.

f. SDGs Village number 6: Villages deserve Clean Water and Sanitation; this diction was chosen over clean water and sanitation or access to clean water and sanitation.

g. SDGs Village number 7: Clean and Renewable Energy Village, this diction was chosen instead of affordable and clean energy or clean and affordable energy.

h. SDGs Village number 8: Equal Village Economic Growth, this diction was chosen instead of decent work and economic growth or decent work and economic growth.

i. SDGs Village number 9: Infrastructure and Village Innovation conforming to the requirement, this diction was chosen over the industry, innovation, and infrastructure.

j. SDGs Village number 10: Villages Without Gaps, this diction was chosen rather than reducing inequalities.

k. SDGs Village number 11: Safe and Comfortable Village Settlement Areas, this diction was chosen instead of sustainable cities and communities. 
International Journal of Social Science (IJSS)

Vol.1 Issue.5 February 2022, pp: 739-746

ISSN: 2798-3463 (Printed) | 2798-4079 (Online)

DOI: https://doi.org/10.53625/ijjss.v1i5.1318

1. SDGs Village number 12: Environmentally conscious village consumption and production, this diction was chosen instead of responsible consumption and production.

m. SDGs Village number 13: Villages Responding to Climate Change, this diction was chosen instead of climate action or handling climate change. Because climate refers to regional to global conditions, the leading village role is not to handle it but to respond to climate change mitigation.

n. SDGs Village number 14: Village Concern to Marine Environment: Instead of living below water or maintaining marine ecosystems, this diction was chosen.

o. SDGs Village number 15: Village Concern to Land Environment, this diction was chosen instead of living on land or maintaining terrestrial ecosystems.

p. SDGs Village number 16: Peaceful Justice Village, chosen this diction over peace, justice, and vital institution.

q. SDGs Village number 17: Partnership for Village Development, this diction was chosen rather than a partnership for the goals or partnerships to achieve goals.

r. SDGs Village number 18: Dynamic Village Institutions and Adaptive Village Culture, this additional diction shows the uniqueness of Indonesian village development.

Rural development is a strategy designed to improve social and economic welfare in specific community groups, rural poverty (World Bank, 1975). According to Villages Act Number 6 of 2014, village development is an effort to improve the quality of life and livelihoods for the maximum welfare of rural communities. The purpose of village development in the explanation of the law is to improve the welfare of rural communities and the quality of human life as well as poverty alleviation through the fulfilment of basic needs, development of facilities and infrastructure, development of local economic potential, and sustainable use of natural resources and the environment(Kuncoro;2019). Thus, the Village SDGs is an integrated effort to realize the acceleration of sustainable development goals through strengthening typology; a village without poverty and hunger, an economic village that grows evenly, a village that cares about health, a village that cares about the environment, a village that cares about education, a women-friendly village, a networked village, and a culturally responsive village.

2. $\quad$ Village Fund

Letty Aziz (2016:198), several important aspects need to be considered to measure the effectiveness of using village funds. They are (a) objectives achievement that the use of village funds is effective if their use is corresponding to the priority requirements so that the objectives are achieved; (b) timeliness, the process of fund's disbursement and use conforming to the time of activities execution that has been planned until the end of activities; (c) according to the benefits, village funds contribution arrives at all village communities as program recipients; and (d) the results are in line with community expectations.

Anggoro Hadi (2018:19) the blessing of the Village Law is not just village funds. The blessing of the Village Law that is far more substantive and meaningful is its efforts to restore village sovereignty and independence and recognition and respect. Currently and in the future local talents have the authority to regulate and manage all government affairs, development, empowerment, and village community development within the scope of the local village scale.

Village funds are sourced from the APBN (state budget) intended for villages transferred through the district/city regional budget. These funds are used to finance government administration, implementation of development, community development, village community empowerment, disaster management, emergencies, and urgent village needs.

\section{A. SDGs Village}

The role of the government in accelerating the achievement of sustainable national development goals by using the Village Fund in Gadingrejo Village, Kepil Subdistrict, Wonosobo Regency, will be studied from six dimensions. They are (1)Prosperous People, (2) Natural balance, (3) Village prosperity, (4) Peace, (5) Partnership, and (6) Village Institutions and Wisdom.So when synergized to use village funds, it is to improve the welfare of rural communities, quality of human life, and poverty alleviation through fulfilling basic needs, developing village facilities and infrastructure, developing local economic potential, and sustainably utilizing all-natural environmental resources. So the development carried out in Gadingrejo village should be evenly distributed and reach every region and existing elements, for example, residential areas and agricultural areas, activities related to the life activities of the Gadingrejo community.

In the implementation of village development carried out by the village officials of Gadingrejo, it is stated in Village Regulation Number 2 of 2019 concerning the Village Medium-Term Development Plan (RPJM Desa).The Village RPJM elaborates the vision, mission, and Village Head program compiled by the Village RPJM Drafting Team coordinated by the Village Head with input from the community involved in the village condition assessment 
(PKD). Its activity is an assessment to formulate problems, causes, potentials, alternative actions and determine appropriate actions in the village. Village conditions are assessed using village portrait techniques, seasonal calendars, institutional diagrams, focused group discussions, and community consultations.

Technical discussions in community discussions (PKD), community meetings, Commission Meetings, and Plenary Meetings are integral to the planning document's preparation process.Community involvement is an essential factor considering that the community is part of the social structure expected to support achieving the goals of this development plan. The purpose of preparing this Village RPJM is so that the Village Government and Village Communities have the foundation and guidelines in implementing and undertaking development in the village for the next 6 (six) years. The objectives of preparing this Village RPJM are:

a. Implementing a Participatory Village Development Planning Pattern

b. Improving Community Empowerment so that all villagers can actively participate in the entire development process with the available capabilities, opportunities, and speed.

c. Improving the quality of village development planning is determined based on a study of the problems, needs, and available resources.

d. Developing self-reliance and community cooperation towards creating development implementation that relies on the strength of the community itself.

e. Strengthening community readiness in welcoming and supporting development programs in the village.

f. Establishing village development plans conforming to the community requirements and local conditions, and

g. Creating a sense of community ownership and responsibility towards village development programs.

The Village Medium-Term Development Plan, from now on abbreviated as (RPJM-Desa) is a planning document for 6 (six) years that contains the direction for village development policies, the direction of village financial policies, general policies, and programs, and the Regional Apparatus Organization (OPD) program. Cross OPD and regional priority programs, accompanied by a work plan.

The Village Government Work Plan, from now on abbreviated as RKP Desa, is a planning document for 1 (one) year which is an elaboration of the Village RPJM which contains the design of the village economic framework, taking into account the updated funding framework, priority village development programs, work plans, and funding as well as forward forecast. Whether implemented directly by the village government or pursued by encouraging community participation, the program refers to the Regional Government Work Plan and Village RPJM. The RKP Village is an activity proposal that uses funds with transparent sources, both from the APBN, APBD (Provincial, Regency/City), Village Budget, Self-help, and Cooperation with third parties.

Funds sourced from the APBN are village fund grants and the implementation of sustainable development in Gadingrejo village. Based on the Village Budget, it is carried out for changes in the development/hardening of the main village roads in 6 (six) hamlets. Meanwhile, conforming to the observation result in the field, this program is being carried out temporarily. The officials also consider the covid pandemic period, so some funds are allocated for disaster management (Village-level Micro PPKM). BLT Village in the face of the COVID-19 pandemic.

1. Prosperous People

In this dimension, the Village SDGs ensure that all villagers are free from poverty and hunger in all its forms. Moreover, it ensures that all villagers can fulfill their potential in dignity, have an equal position, and get the right to live with dignity in a healthy environment.

2. Natural balance

In this dimension, the Village SDGs seek to protect nature from the adverse impacts of human activities, such as environmental change and irresponsible use of natural resources, so that the protection process can support the needs of present and future generations.

3. Village Prosperity

The Village SDGs ensure that all villagers have a prosperous and sufficient life in this dimension. Economic, social, and technological progress can occur in harmony side by side with nature.

4. Peace

The Village SDGs seek to develop peaceful, just, and inclusive villagers free from fear and violence in this dimension. There is no sustainable development without peace and social security, and vice versa, there is no peace and social security without sustainable development.

5. Partnership

In this dimension, the Village SDGs are present to mobilize the necessary means so that villages can collaborate with other villages and collaborate with third parties for sustainable development. This achievement can only be achieved through close cooperation with the principle of high solidarity to 
International Journal of Social Science (IJSS)

Vol.1 Issue.5 February 2022, pp: 739-746

ISSN: 2798-3463 (Printed) | 2798-4079 (Online)

DOI: https://doi.org/10.53625/ijjss.v1i5.1318

accelerate and improve the implementation of village governance, implementation of village development, village community development, and village community empowerment.

6. Village Institutions and Wisdom

In this dimension, the Village SDGs are present to ensure the strength of village institutions, recognize respect and protection of indigenous peoples' rights, and realize strategies to empower custom, local wisdom, and culture of rural communities. The Village SDGs are present as an effort or process of change to achieve welfare or quality of life for village communities who have high social piety, respect their local customs and culture, and local community beliefs.

\section{B. The Contribution of Village Funds to the Achievement of Village SDGs in Gadingrejo Village}

Priority for village development has now been directed towards sustainable development goals (SDGs). In the Regulation of the Ministry of Villages, Development of Disadvantaged Regions, and Transmigration of the Republic of Indonesia Number 13 of 2020 concerning Priorities for the Use of Village Funds in 2021, it is stated that the Village SDGs is an integrated effort to realize a village. The target is the village without poverty and hunger. The economic village grows evenly, the village cares about health, the village cares for the environment, and the village cares about education, women-friendly villages, networked villages, and culturally responsive villages to accelerate the achievement of the Sustainable Development Goals.

The contribution of village funds to the achievement of the Village SDGs dimensions in Gadingrejo Village is still limited and cannot yet cover all existing dimensions. In the report on the realization of the implementation of the Village Budget in Gadingrejo Village in the last semester, it can be seen that the contribution of village funds for achieving the Village SDGs dimensions is not optimal. As stated by Mr. Tegeno, Head of Gadingrejo Village,

"Of the total village fund budget in 2021 received by the Gadingrejo Village government of $1,116,698,000$ IDR, the realized funds were 1,031,280,000 IDR, and SiLPA 92,071,000 IDR in its use is still dominated to realize the third dimension of the Village SDGs, namely Village Prosperity. In which the details in using these funds are for basic infrastructure development as much as 519,000,000 IDR (1/2022)."

This statement shows that the contribution of village funds in Gadingrejo Village has not fully supported the achievement of the Village SDGs dimensions evenly. The Gadingrejo Village government continues to use the funds because it is following the mandate of the community members' proposals during the RKP Village Development Plan Deliberation and has been stated in the Village APB document.

Meanwhile, the contribution of village funds to achieve the first dimension of the Village SDGs, Prosperous Villagers, is carried out with cross-sectoral efforts. The effort was explained by Ery Saptoyo, Head of the Welfare Section as Executor of Budget Activities (PKA) in Gadingrejo Village,

"The contribution of village funds in order to successfully achieve the Village SDGs dimensions, prosperous village residents, is carried out by procuring education sub-sector activities of $108,850,000$ IDR and Health sub-sector of 264.620.000 IDR (1/2022)."

The statement above shows that the village fundscontributionfor achieving the SDGs dimensions of the Villages of Prosperous Villagers has been implemented but has not been maximized. The percentage contribution of village funds for achieving the Village SDGs is still low. Meanwhile, village funds' contribution in achieving the Village SDGs dimensions of Natural Balance, Peace, Partnership, and Institutional and Village Wisdom has not been fully funded and implemented.

\section{CONCLUSION}

Acceleration to achieve sustainable national development goals through the implementation of the Village SDGs is directed by the Permendesa PDTT regulation on the priority use of village funds. Therefore, efforts to reach the SDGs Village dimension are critical to realizing the acceleration of sustainable development goals through strengthening typologies: villages without poverty and hunger, economic villages growing evenly, villages concerned with health, villages concerned with the environment, villages concerned with education, women-friendly villages, networked villages, and culturally responsive villages.

The results show that the contribution of village funds to the acceleration of achieving sustainable development continues to be carried out in Gadingrejo village. However, due to the limited budget, development is carried out in stages and corresponds to the existing budget, which is carried out per budget year and for village funds for the 2021 fiscal year. Due to the Covid-19 pandemic outbreak, some budgets were cut and experienced refocusing.

In the case of Gadingrejo Village, the contribution of village funds to the achievement of the six village SDGs dimensions has not been fully implemented. The contribution of new village funds is limited to funding the 
dimensions of the SDGs for the Village Prosperity by undertaking the village main road construction or hardening and the dimensions of the SDGs for the Prosperous Villagers through activities in the education and health subsectors.However, if it continues to improve and the capacity of village government officials to understand the dimensions of the Village SDGs is improved, Gadingrejo Village can become a village that can maximize the Village SDGs dimensions as an effort; to accelerate the achievement of sustainable national development goals.

\section{BIBLIOGRAPHY}

(A. Halim Iskandar, 2020; Ayu \& Sasambe, n.d.; Hariawan Bihamding, 2017; John W Creswell, 2015; Oekan S Abdoellah, 2017; - Regulation of the Ministry of Villages and PDTT Number 17 of 2019 concerning General Guidelines for Development and Empowerment of Village Communities, n.d.; - Government Regulation Number 43 of 2014 concerning the Implementation of the Provision in the Village Act Number 6 of 2014, Junction Government Regulation Number 47 of 2015 concerning Amendments to the Implementation of the Provision in the Village Act No. 6 of 2014, n.d.; Presidential Regulation of the Republic of Indonesia Number 59 of 2017 concerning Implementation of the Achievement of Sustainable Development Goals, n.d.; Permendagri Number 20 of 2018 concerning Village Financial Management, n.d.; Village Act Number 6 of 2014, n.d.; Prof. Mudrajad Kuncoro, 2018, 2019; Sutrisna, n.d.; Yamin, 2018) 